\title{
Interpretive Community 2.0: How Blogs and Twitter Change International Law Scholarship
}

\author{
Ralph Janik* \\ University of Vienna, Vienna, Austria \\ ralph.janik@univie.ac.at
}

Abstract

841

$\begin{array}{ll}\text { Keywords } & 842\end{array}$

I. Introduction 842

II. The Peculiarities of International Law Scholarship 845

1. An Interpretive Community ...

2. ... or an Interpretive Society? 847

III. Social Media and International Law Academia: Risks and Opportunities 849

$\begin{array}{ll}\text { 1. Challenging Gatekeeping } & 851\end{array}$

2. Academic Tortoises $\quad 856$

3. Global Reach and Access Inequality 858

4. Two Practical Examples of the Interaction Between Social Media and International

Law $\quad 860$

a) The Good: A Blog Survey on the US-Led Strikes against Assad and the Curious Case of Article 2(4)

b) The Bad (and the Ugly?): The International Criminal Court vs. the 'Blogosphere'

IV. Conclusion
860

862

865

\begin{abstract}
Using Stanley Fish's description of interpretive communities, this paper examines the impact of Social Media as an additional tool in international law scholarship. On the one hand, it might work against Western-centrism as debates could become more open and accessible for academics from different backgrounds and regions. On the other hand, there is a real risk that some of the downsides we may observe in political online debates - polarisation and a decline of basic decency - could also extend to the academic realm. It is about time to ask ourselves whether and how we can ensure that the benefits outweigh the costs.

The following article is divided into two main parts: The first will refer to Stanley Fish's notion of 'interpretive communities' to outline how Social

\footnotetext{
* The author teaches international law at the University of Vienna, SFU, Andrassy University, and Webster Private University Vienna.
} 
Media may influence the pre-existing special and distinctive features of international law scholarship. The second, then, will show how the benefits of blogging and tweeting outweigh justified worries: Social Media increases participation in and readership of international law-related debates and allows qualified commentary to be published (almost) instantly.

\section{Keywords}

social media - internet law - interpretive communities - international law theory

\section{Introduction}

'Web 2.0' or, to use the nowadays more fashionable term, Social Media, has brought profound changes to how we communicate, share ideas, or get information. Obviously enough, this general transformation of mere passive consumers into producers of online content also has a tremendous impact on the science of international law. Long gone seem the days of the Westphalia myth, of Gentili or Grotius, the later rise of legal scientificism and international law societies, ${ }^{1}$ or regional or national self-encapsulation of scholars due to geographic and other obstacles causing academic time-lags when debating new judgements, treaties, or other impactful international events.

You can now discuss anything in real time, anywhere, with anyone. In the age of globalisation, hardly an aspect of our lives escapes international regulation: ${ }^{2}$ much to talk and disagree about, not only among scholars but also the (sometimes neglected) countless practitioners behind the myriad of abstract entities we describe as subjects of international law, ${ }^{3}$ chief among them the 200 or so states - which often speak with two or even more different tongues, as the government may differ from the findings of national courts -, uncounted international organisations, or international courts and tribunals.

In this setting, the lines between theory and practice, between official and unofficial statements, both on- and offline, are often blurred: Law

1 See, above all, Martti Koskenniemi, The Gentle Civilizer of Nations: The Rise and Fall of International Law 1870-1960 (Cambridge: Cambridge University Press 2001).

2 See David J. Bederman, Globalization and International Law (New York: Palgrave Macmillan 2008).

3 See Andrea Bianchi, International Law Theories: An Inquiry into Different Ways of Thinking (Oxford: Oxford University Press 2016), 297-298; for a specific and extensive elaboration on the role of individuals behind an abstract entity like the International Criminal Tribunal for Rwanda (ICTR), see Nigel Eltringham, Genocide Never Sleeps: Living Law at the International Criminal Tribunal for Rwanda (Cambridge: Cambridge University Press 2019). 
professors may be appointed as judges, arbiters, or special rapporteurs, while legal advisors or members of courts give lectures, participate in conferences, and engage in academic writing. One of the peculiarities of international law is the broad array of individuals from different professional backgrounds and countries contributing to the evolvement of new rules and the adaption of existing ones through revolving doors - a group Oscar Schachter famously described as the invisible college of international lawyers'. ${ }^{4}$

From a more general perspective, we may further observe that this college equally forms what Stanley Fish famously described as an 'interpretive community', ${ }^{5}$ namely

'not so much a group of individuals who shared a point of view, but a point of view or way of organizing experience that shared individuals in the sense that its assumed distinctions, categories of understanding, and stipulations of relevance and irrelevance were the content of the consciousness of community members who were therefore no longer individuals, but, in so far as they were embedded in the community's enterprise, community property'. ${ }^{6}$

As I will show below, Social Media challenges both Schachter's college and the generally established thinking on interpretive communities in several ways: First, it has the potential to open academic membership and the associated admission criteria. Second, the already ongoing inflation of scholarship has now expanded even further since traditional venues have been supplemented by international law-blogs, some of which have established themselves as new intermediary fora between the lengthy and all too often painful peer review-process of journals and completely non-curated ad hoccomments. Third, more and more international lawyers go beyond any

4 Oscar Schachter, 'The Invisible College of International Lawyers', Nw. U.L. Rev. 72 (1977), 217-226.

5 Applying Fish's concept to international law(yers) is not new, see already Ian Johnstone, 'Treaty Interpretation: The Authority of Interpretive Communities', Mich. J. Int'l L. 12 (1991), 371-419; Detlev F. Vagts, 'Treaty Interpretation and the New American Ways of Law Reading', EJIL 4 (1993), 472-505; for more recent scholarship in this regard, see Michael Waibel, 'Interpretive Communities in International Law' in: Andrea Bianchi, Daniel Peat and Matthew Windsor (eds), Interpretation in International Law (Oxford: Oxford University Press 2015), 147-165; Jean d'Aspremont, Epistemic Forces in International Law: Foundational Doctrines and Techniques of International Legal Argumentation (Cheltenham/Northampton: Edward Elgar Publishing 2015), 18; d'Aspremont repeated these introductory elaborations in his book chapter 'The Professionalisation of International Law' in: Jean d'Aspremont, Tarcisio Gazzini, André Nollkaemper, and Wouter Werner (eds), International Law as a Profession (Cambridge: Cambridge University Press 2017), 19-37 (29 f.).

6 Stanley Fish, Doing What Comes Naturally: Change, Rhetoric, and the Practice of Theory in Literary and Legal Studies (Durham and London: Duke University Press 1989), 141. 
academic intermediaries by using personal Social Media accounts - first and foremost Twitter, but also Facebook - to promote themselves, share their work, exchange with colleagues and the broader public, voice their personal (sometimes political, sometimes legal) views, or simply seek mutual selfassurance that international law indeed exists.

International law scholars have already noted a number of ensuing pros and cons or risks and chances of these developments: Increasing participation by less-known voices and a corresponding further democratisation of debates $^{7}$ vs. fears over less restrictive standards of scholarly production ${ }^{8}$ and a digitalised Matthew effect where big names retain disproportionate influence; ${ }^{9}$ emancipation from big publishers to acquire broader readership for one's own work ${ }^{10}$ vs. academic self-marketing, often coupled to self-restraint to avoid offending one's readers; ${ }^{11}$ new possibilities for permanent academic exchange vs. digital polarisation caused by emotions, biases, or even ad hominem-arguments leaving little room for the principle of charity or other argumentative tools to ensure an open, fair, and rational debate (if such a thing may even exist);12 or the value of quick and still qualified ad hoccomments on new developments or events ${ }^{13}$ vs. a 'speed kills'-commenting mentality at the expense of substance. ${ }^{14}$

7 Carsten Stahn and Eric de Brabandere, "The Future of International Legal Scholarship: Some Thoughts on "Practice”, "Growth", and "Dissemination”', LJIL 27 (2014), 1-10.

8 Jean d'Aspremont and Larissa van den Herik, 'The Public Good of Academic Publishing in International Law', LJIL 26 (2013), 1-6.

9 Hannah Birkenkötter, 'Blogs in der Wissenschaft vom Öffentlichen Recht. Ein Beitrag zur Erschließung neuer Formate' in: Andreas Funke and Konrad Lachmayer (eds), Formate der Rechtswissenschaft (Weilerswist-Metternich: Velbrück Wissenschaft 2016), 117-140; Christine Schwöbel-Patel, 'Insta-Scholarship: the Self-Branding Practices of the "Digital Humanitarian"' in: Lianne J. M. Boer and Sofia Stolk (eds), Backstage Practices of Transnational Law (Oxon and New York: Routledge 2019), 125-142.

10 Roger Alford, 'Self-Publishing Legal Scholarship', 12 April 2011, <http://opiniojuris. $\operatorname{org} />$.

11 Schwöbel-Patel (n. 9) explicitly mentions Philippe Sands as an example of a particularly influential international law scholar with a personal Twitter account; on Social Media becoming part of regular academic profiles see also Stahn and de Brabandere (n. 7); further highlighting the seemingly increasing need to use Social Media as part of self-promotion, Dapo Akande's campaign for a seat in the International Law Commission has set up a distinct Twitter account in January 2021 (@UKILCCampaign); Akande, one of the foremost contributors to EJIL:Talk!, has also been nominated by Nigeria, see $<$ https://www.law.ox.ac.uk $>$.

12 See the discussion of the pros and cons of blogging by Jean d'Aspremont, 'In Defense of the Hazardous Tool of Legal Blogging', 6 January 2011, <www.ejiltalk.org/>.

13 Antoine Duval, 'Publish (Tweets and Blogs) or Perish? Legal Academia in Times of Social Media', Tilburg Law Review 23 (2018), 91-108.

14 Constance Duncombe, 'The Politics of Twitter: Emotions and the Power of Social Media', International Political Sociology 13 (2019), 409-429; Larissa van den Herik, 'Introduction: LJIL in the Age of Cyberspace', LJIL 25 (2012), 1-8; see also Schwöbel-Patel (n. 9). 
Addressing these issues on the basis of understanding international law academia as one or several interpretive communities, I will argue that Social Media's positively (!) disruptive potential has not yet been fully exploited. A small caveat, however, is due at this point: In times of rapid technological change, my elaborations on the possible effect of Social Media and the associated dangers or opportunities may read like odd speculations in a few decades. In hindsight, I might be making a fool of myself. A small risk I am willing to take.

\section{The Peculiarities of International Law Scholarship}

\section{An Interpretive Community ...}

The following observations on the (changing) dynamics of international law academia proceed from the simple observation that legal documents and corresponding comments in blog entries or tweets are, at the end of the day, texts. Scholarly research has always been an act of 'storytelling' based on the construction, de-construction, and exchange of arguments, coupled to the underlying hope of establishing authority and/or convince not only one's academic peers but also practitioners of all sorts. ${ }^{15}$ International lawyers examine how legal documents came into being and how these 'living instruments' ${ }^{\prime 16}$ are being changed over time while respecting that their interpretation depends on who is working with them - one (applicant) state's prosecutor could be another (respondent) state's defence counsel.

These trends reflect striking parallels to literature and literature theory:17 different contents, similar processes. From this perspective, we may further wonder to what extent the 'invisible college of international lawyers' also features elements of an interpretive community and whether it can also exist online and in a legal academic setting.

15 This analogy has been pointed out by Bianchi (n. 3), 291-293.

16 The European Court of Human Rights (ECtHR) first used this term to describe the European Convention on Human Rights in 1978, see ECtHR, Tyrer v. the United Kingdom, judgment of 25 April 1978, no. 5856/72, para. 31.

17 See, among countless others, Ekaterina Yahyaoui Krivenko, 'International Law, Literature and Interdisciplinarity', Law and Humanities 9 (2015), 103-122; Ekaterina Yahyaoui Krivenko, 'Engaging International Law and Literature with Kafka, Deleuze and Guattari' in: Christina Binder, Mary E. Footer and August Reinisch (eds), International Law and .... Select Proceedings of the European Society of International Law, Vol. 5 (Oxford and Portland, Oregon: Hart Publishing 2014), 393-404; Andrea Bianchi, 'Terrorism and Armed Conflict: Insights from a Law \& Literature Perspective', LJIL 24 (2011), 1-21; on law and literature in general, see James Boyd White, 'Law and Literature: “No Manifesto”', Mercer. L. Rev. 39 (1988), 739-751. 
At the outset, Fish coined this idea under completely different circumstances, namely the final remarks of his discussion of a commentary on poems of John Milton from 1976. Yet, they were never confined to the 'real', i. e. offline world but could equally be applied to older long-distance, impersonal academic exchange. Fish always focused on communication as such, not the means. Literature theorists and lawyers have long shared the feeling of wondering whether they have read the same text as their counterparts. In an attempt to break free from what Fish described as the 'tyranny of the text' $^{18}$ at another occasion, he raised the Gretchenfrage of whether there can be an objective understanding in such an inherently subjective experience as reading poetry: Is the reader or the text the true source of meaning, can different readers of the same text ever come to the same conclusions and, if so, how and why?

Fish's answer was that it was indeed possible to distinguish between the informed expert with the necessary background knowledge to tell others what they ought to think and those who are doomed to fail at truly understanding a given text.

In this sense, neither the interpreter nor the text 'produce meanings and are responsible for the emergence of formal features' but rather 'interpretive communities'19 - exclusive debate clubs 'made up of those who share interpretive strategies not for reading (in the conventional sense) but for writing texts, for constituting their properties and assigning their intentions'.20

Lastly, we need to ask the fundamental question whether there can really be an interpretive community in international law. While the ability of engaging in interpretation is a human trait, the strategies and methods behind it are being learned and can thus be changed, exchanged, or forgotten. One and the same legal document is not only transformed over time ${ }^{21}$ but also by the composition of the respective community working with it. There is no such thing as a stable text.

As will be shown below, the real challenge posed by Social Media is its gradual expansion of membership in international law's interpretive community.

The increased possibilities for truly worldwide academic participation highlight how its allegedly universal character may simultaneously prevent

18 Stanley Fish, Is There a Text in This Class? The Authority of Interpretive Communities (Cambridge, Massachusetts: Harvard University Press 1980), 7.

19 Fish (n. 18), 14.

20 Stanley Fish, 'Interpreting the "Variorum", Critical Inquiry 2 (1976), 465-485 (483).

21 One may thus consider the notion of intertemporal law as an artificial attempt to rediscover lost interpretation strategies, see Philip C. Jessup, 'The Palmas Island Arbitration', AJIL 22 (1928), 735-752. 
scholars from ever developing a truly shared set of techniques, understandings, and language for interactions between liberal and illiberal states, the West and the rest, North and South, poor and rich, developing and developed, former colonial powers and former colonised peoples, and so on.

\section{2. ... or an Interpretive Society?}

Due to this heterogeneity, international lawyers not only have much to discuss but are also doomed to disagree. To begin with, international law results from the well-known constant tension between the desire to justify governmental practices and a collective endeavour to overcome individual state-interests. $^{22}$ Scholars are often practitioners et vice versa. Already Schachter raised the still-unsettled 'question of objectivity in international law' as the fundamental problem for the invisible college since

' $[\mathrm{t}]$ he mingling of the scholarly and the official affects both categories, and often creates tension as individuals move from one role to another or perceive themselves as acting in the dual capacity of objective scientist and government advocate. Concern over this kind of "dédoublement fonctionnel" has been manifested by both government officials and scholars. Government officials often tend to suspect or disdain "objective" views as divorced from reality and insufficiently responsive to national aims. This attitude can have a significant impact on some international lawyers. It may lead them to adopt a strong "national interest" and "realpolitik" line, or it may convince them of the necessity of foregoing this dual capacity and maintaining their objectivity removed from government influence'. ${ }^{23}$

Probably even more importantly for present purposes, legal education pulls into two opposite directions here: On the one hand, Western conceptualisations and academic institutions are still predominant: ${ }^{24}$ the 'invisible college' was and is not truly 'global' but, as Anne Peters has noted, 'an elite college of scholars of the developed world, a college in which academics from the so-called Global South are relegated to the role of the eternal students'. ${ }^{25}$

22 Martti Koskenniemi, From Apology to Utopia: The Structure of International Legal Argument (Cambridge: Cambridge University Press reissue 2006).

23 Schachter (n. 4), 218.

24 See, among others, James Thuo Gathii, 'International Law and Eurocentricity', EJIL 9 (1998), 184-211 or Lauri Mälksoo, 'Civilizational Diversity as Challenge to the (False) Universality of International Law', Asian Journal of International Law 9 (2019), 155-164.

25 Anne Peters, 'International Legal Scholarship Under Challenge' in: Jean d'Aspremont, Tarcisio Gazzini and André Nollkaemper (eds), International Law as a Profession (Cambridge: Cambridge University Press 2017), 117-159 (119). 
On the other hand, the 'landmark judgments' or approaches towards international law depend on where a lawyer comes into contact with it. We can no longer deny that international law is not truly international..$^{26}$ Lawyers from different countries or regions operate with completely different understandings of central terms like sovereignty - the 'S-word' 27 -, human rights, or democracy. Those who studied and work in more dominant states view the world with different eyes than their peers in weaker ones, those from the Global South experience international law different than scholars in richer countries, ${ }^{28}$ governments may start targeted Social Media campaigns to promote their legal views (such as the one launched by Israel against the International Criminal Court after the Office of the Prosecutor announced its investigation of the situation in Palestine ${ }^{29}$ ). Great Powers are more assertive and keener on protecting their freedom to act while smaller ones emphasise the need for international cooperation and the rule of $\mathrm{law}^{30}-$ if you have no weapons, you are left with words, a cynic could say.

Looking at the permanent five of the Security Council, for example, one can see at least three, maybe four, possibly even five different understandings and - in the case of Russia and China, outright instrumentalisation - of international law: The United States (US) oscillates between isolationism and partly geopolitical, partly humanitarian interventionism, between democracy promotion as part of constructing and defending a rules-based 'liberal world order' and unilateralism whenever it suits its sovereign interests. ${ }^{31}$ France and the United Kingdom, as the other two members of the community of liberal states, face the difficult task of coping with their relative decline: While the

26 Anthea Roberts, Is International Law International? (Oxford: Oxford University Press 2017); see also Martti Koskenniemi, The Politics of International Law (Oxford and Portland, Oregon: Hart Publishing 2011), 50: 'Instead of a "common law of mankind", international law becomes its ideological contrary; a divisive weapon; a protective shield under which the privileges of some can be upheld against the claims of others; and a unilateral weapon in the hands of the hegemon.'

27 Louis Henkin, 'That "S" Word: Sovereignty, and Globalization, and Human Rights et cetera', Fordham L. Rev. 68 (1999), 1-14.

28 See e. g. Jochen von Bernstorff and Philipp Dann (eds), The Battle for International Law: South-North Perspectives on the Decolonization Era (Oxford: Oxford University Press 2019) or the TWAIL Perspectives on ICL, IHL, and Intervention, AJIL Unbound 109 (2015) $<$ https://www.cambridge.org/>.

29 Israel worked with google ads and created a website dedicated to explain why the ICC does not have jurisdiction over the situation in Palestine, see the criticism by Kevin John Heller, $<$ https://twitter.com/kevinjonheller/status/1372333192221319168>.

30 Austria, for example, has been coordinating the 50 states part of the 'Group of Friends of the Rule of Law' since 2005, see <https://www.bmeia.gv.at>.

31 'Multilateral when we can, unilateral when we must', as Madeleine Albright put it, quoted in Joy Gordon, 'When Unilateralism is Invisible: A Different Perspective on the Oilfor-Food Scandal', Global Governance 13 (2007), 59-77 (59). 
former also takes a leading role in the European Union, ${ }^{32}$ the latter has voted to leave and walk a still undefined route.

Meanwhile, Russia and China like to portray themselves as anti-liberal antagonists in the sense that both defend a much more robust, traditional understanding of sovereignty and a preference for pluralism on the international level (of political systems, that is) while seeking homogeneity (e.g. when it comes to party politics, minority rights, or freedom of speech) inside of states. ${ }^{33}$

For these reasons, the common argumentative ground of international law academics from different national or regional backgrounds is shaky. The lack of coherent shared legal techniques, understanding of the law and its conflation with politics make it difficult to draw the line between dogmatic arguments and moral philosophy, legal theory, or political science. ${ }^{34}$

Perhaps the interpretive community of international lawyers should thus rather be described as an interpretive society, i.e. one with only weak terminological and dogmatic bonds. ${ }^{35}$ International law academia is as fragmented as its field of activity. There is not one, but several interpretive communities.

\section{Social Media and International Law Academia: Risks and Opportunities}

Social Media has added another layer to international law's complex web of actors and approaches. To begin with, the abundance and lack of originality of scholarship has already been bemoaned before the rise of legal blogs ${ }^{36}$ Further growth and the corresponding impossibility to keep track of

32 In the 2019 Aachen treaty, France and Germany, as the two foremost powerhouses of the European Union, decided to 'closely coordinate their positions [...] also in accordance with the positions and interests of the European Union' and pledged to 'work together to promote the positions and promises of the European Union in connection with global challenges and threats'. The treaty can be accessed at $<$ https://www.bundesregierung.de $>$ (German version) or $<$ https://www.elysee.fr $>$ (French version).

33 See Rein Müllerson, 'Ideology, Geopolitics and International Law', Chinese Journal of International Law 15 (2016), 47-73.

34 This conflation has been observed by Anne Peters, 'Die Zukunft der Völkerrechtswissenschaft: Wider den epistemischen Nationalismus', HJIL 67 (2007), 721-776 (750-751).

35 On this distinction in international law in general, see Russel Buchan, International Law and the Construction of the Liberal Peace (Oxford and Portland, Oregon: Hart Publishing 2013).

36 David J. Bederman, 'What's Wrong with International Law Scholarship? I Hate International Law Scholarship (Sort of)', Chinese Journal of International Law 1 (2000), $75-84$ (81). 
what has been said, by whom, and where adds another dimension to the preexisting problem of academic inflation.

What is more, academia is not immune to the general risk of creating or further strengthening digital 'echo chambers' where confirmation biases run rampant and users are increasingly detached from other viewpoints. However, echo chambers are usually not as isolated as commonly thought. ${ }^{37}$ Furthermore, such tendencies can also be observed in the traditional academic sphere. There is a thin line between the understandable ambition to preserve and strengthen regionalised or national approaches in smaller or Eastern European countries and an almost complete self-encapsulation as can be observed in Russia. ${ }^{38}$

In this connection, Social Media accounts and user comment sections in newspapers (or blogs, for that matter) further stand accused of bringing out the worst in people, from not even bothering to read others' arguments carefully and being ready to overthink one's position to trolling or even hate speech. By now we have all witnessed the spread of online hostility, not only by anonymous accounts but even official ones, most prominently Donald Trump in his capacity as the 45th president of the United States. ${ }^{39}$ The absence of many of the social restraints operating in the 'real world' may lead to a collapse of even minimum standards of civility. ${ }^{40}$

37 On these social networks phenomenon in general and challenging the view of rising online 'segregation' in a non-scholarly context, see Seth Flaxman, Sharad Goel and Justin M. Rao, 'Filter Bubbles, Echo Chambers, and Online News Consumption', Public Opinion Quarterly 80 (2016), 298-320.

38 For example, the Polish Yearbook of International Law explicitly states its 'preference for Central Eastern European scholarship and manuscripts which focus on the region', <http:// www.pyil.inp.pan.pl>; the Finnish Yearbook of International Law, while open to submissions from all over the world, explicitly 'aspires to honour and strengthen the Finnish tradition in international legal scholarship', see <http:/fsil.fi/fybil/>; Russian scholarship is a particularly drastic example since most publications are being written in Russian and primarily aimed at a domestic audience, see Lauri Mälksoo, Russian Approaches to International Law (Oxford: Oxford University Press 2015).

39 Brian L. Ott, 'The Age of Twitter: Donald J. Trump and the Politics of Debasement', Critical Studies in Media Communication 34 (2017), 59-68; on the question to which extent Tweets by governments and states leaders might be interpreted as opinio juris and state practice, see already Special Rapporteur Michael Wood's Second report on identification of customary international law, 22 May 2014, A/CN.4/672, para 29: '[...] in determining what the relevant practice actually is and to what extent it is indeed accepted as law, and different weight may be given to different evidence [...] the care with which a statement is made is a relevant factor; less significance may be given to off-the-cuff remarks made in the heat of the moment.'

40 See, among countless others, Emma A. Jane, 'Flaming? What Flaming? The Pitfalls and Potentials of Researching Online Hostility', Ethics and Information Technology 17 (2015), 6587; Ben Martin and Thera Rising, 'Why is Everyone on the Internet so Mean?', 8 February 2018, <http://thera-rising.com/>; Erin E. Buckels, Paul D. Trapnell and Delroy L. Paulhus, 'Trolls Just Want to Have Fun', Personality and Individual Differences 67 (2014), 97-102. 
There is no guarantee that this decline of etiquette witnessed in public debates stops at the academic gates. ${ }^{41}$ One should not forget that traditional communication between scholars is not necessarily a casebook example of courtoisie either. ${ }^{42}$ Cooperation, mutual academic trust, and basic decency can be thwarted: less filters, more problems. There are real psychological risks of being overly confronting when typing blog posts or comments instead of talking in person. 'Publishing' by clicking on 'send'-buttons instead of thinking twice or going through a lengthy peer-review may lead to hostility instead of benevolent interpretation, added confusion instead of clarity, or eagerness to be the 'first mover' when it comes to commenting on new developments instead of exercising scholarly restraint and avoid making a fool of oneself. Non-redacted statements, be they submitted via Twitter accounts, personal blogs, or in the comments-section of blogs - which can, as one should not forget, at times not be deleted or edited by the authors themselves -, might be off the mark.

As indicated, most of these problems are not entirely new. Digital means of communication cannot cause disruption by themselves but rather aggravate existing troubles. Yet, even if they do, I will argue that the benefits for the interpretive community of international law still outweigh the costs. Digital hyperconnectivity enables genuinely global academic exchange and can expose scholars to views outside of their 'bubble', be it from interested laymen or academics from the Global South for whom tweeting or blogging is easier than travelling to conferences. As to the passive side, Social Media can attract much larger audiences than traditional scholarly work and make international law more accessible for regional or academic 'outsiders'. With some sense of naivety, it may ultimately contribute to making international law truly international.

\section{Challenging Gatekeeping}

One of the focal points of academic concerns over Social Media is its most fundamental characteristic, the absence or reduced role of gatekeepers. ${ }^{43} \mathrm{~A}$

\footnotetext{
41 By way of example, the University of Bern updated Social Media guidelines from April 2021 call on its staff to exercise self-restraint and coordinate to a minimum degree within faculties when voicing their opinions, in particular in connection with 'sensitive issues', see $<$ https://www.unibe.ch> and the corresponding comment by Evelyne Schmid <https://verfas sungsblog.de $>$.

42 While I do not want to point fingers here, one recent example of a particularly harsh critique is Carl-Friedrich Stuckenberg's review of Frauke Rostalski's habilitation in ZIS online 4 (2021), 279-297 <http://www.zis-online.com/>.

43 See already Brian Leiter, 'Why Blogs Are Bad for Legal Scholarship', Yale L. J. Pocket Part 116 (2006-2007), 19 September 2006, <https://www.yalelawjournal.org/>.
} 
personal blog or Twitter account is only a few clicks away, no publisher or editor standing in the path of voicing one's opinion, the only barrier being the scrutiny of authorities or readiness of those who feel their reputation is being harmed by online comments to go to court and the corresponding limits of free speech.

By using Social Media, younger scholars or those on the fringes of academia have additional chances to practice legal writing - the very core of their profession ${ }^{44}$ - and gaining access to academic fora. It is e.g. easier for blogs to improve and later publish entries that initially had certain fundamental shortcomings, perhaps attributable to the writer's lack of access to resources, but still develop truly novel thoughts that deserve to be published.

In so doing, however, they might, inadvertently or not, openly or implicitly, defy long-established codes and hierarchies (more on that later). ${ }^{45}$ To prevent or remedy violations of the unwritten rules of international law's interpretive communities, blogs or personal social media accounts will always be tied to some level of explicit (who may publish on a curated blog) or implicit (who 'deserves' an answer in a blog's comments section or on Twitter) gatekeeping.

In general, expertise, evidenced by one's profession, can serve as a 'passport for legal blogging'. ${ }^{46}$ Often enough, membership in international law's interpretive community and hence access to debates is beyond doubt: Bourdieu's critique of the unofficial 'intellectual hit parade' among French think$\mathrm{ers}^{47}$ can easily be transplanted to the field of international law: Some scholars are more often read and cited than others, ${ }^{48}$ receive votes for awards by their

44 Duval (n. 13).

45 D'Aspremont (n. 12).

46 D'Aspremont (n. 12); Birkenkötter (n. 9), 126.

47 To quote Pierre Bourdieu's critique of a ranking of French public intellectuals of all sorts, among them writers, philosophers, or journalists: 'The intellectual hit parade represents a sort of artificial reconstruction, and thus one easier to observe, of the process which is constantly at work in the field of cultural production and which elaborates and defines one of the most powerful representations (because objectified and widely broadcast) of the hierarchy of intellectual values. This process, which is no doubt also equivalent to judicial procedure or, in other words, a process of making up prices (as verdicts of the market, is accomplished through "informal" exchange of private and sometimes confidential judgments ("don't say I said so, but so-and-so's book is absolute rubbish") between journalists, between writer-journalists and journalist-writers, but also through the public verdicts of book reviews, critical works, invitations to broadcast on radio or television, and finally the hit parades, ratings and rankings, not to mention the more traditional acts of institutional consecration, like appointment to an academy, which, essentially, only ratify the whole set of these verdicts, etc.', see Pierre Bourdieu, Homo Academicus (Stanford: Stanford University Press 1984/1988), $259 \mathrm{f}$.

48 See already Fred R. Shapiro, 'The Most-Cited Legal Scholars', JLS 29 (2000), 409-426; see also Lianne J.M. Boer, “The Greater Part of Jurisconsults”: On Consensus Claims and Their Footnotes in Legal Scholarship', LJIL 29 (2016), 1021-1042. 
colleagues, and media attention may not be evenly distributed (obviously enough, not all lawyers want it anyhow). Relatedly, the status of their academic institutions matters just as much as whether they also serve additional functions, from series editors to special rapporteurs or appointments as judges at international courts and tribunals.

The devil in the detail remains. When it comes to one's institutionalised embeddedness, there are difficulties when comparing different academic systems and positions even within Europe, not to speak of the global level. When focusing on legal professionalism, one needs to keep the heterogeneity of the large group of those teaching and researching under precarious conditions in mind: Is it sufficient to be employed to teach one international lawrelated class per year to be counted as an academic? What about retired and well-respected legal advisors without any formal connections to academic institutions? ${ }^{49}$ Could membership in the international law interpretive community even include non-lawyers who are familiar with the basic tenets of the legal field while accepting the limits of their expertise?

The flexibility of interpretive communities' composition can help to fill such gaps. The community itself regulates admission:

'The only "proof" of membership is fellowship, the nod of recognition from someone in the same [interpretive] community, someone who says to you what neither of us could ever prove to a third party: "we know". 50

What thus counts is the stability of interpretive strategies, not that of membership. It ensures that debates will keep going until a collectivelyestablished agreement leading to a text's emancipation from its readers is reached, an outcome prevented by the lack of shared codes and methods between and within interpretive communities. The interpretive battles ${ }^{51}$ will remain alive as long as there is sufficient mutual understanding of the respective others to prevent the weak common ground from breaking apart.

Some forty years after first coining the notion of interpretive communities, Fish further contrasted the interpretive community of law with groups of people forming associations because they 'share some of the same ideas and aims' like fans from the same movies or sports teams. Interpretive communities are rather

49 By way of example, Maurizio Ragazzi, who gave a presentation at the 2014 European Society of International Law meeting agora on international law and theology, described himself as an 'Independent Researcher, former Senior Counsel International Law, World Bank, Washington, D. C.', see <https://esil2014.univie.ac>.

50 Fish (n. 20), 484.

51 Fish (n. 20), 484. 
'made up of those who, by virtue of training, experience, and practice, have internalized the norms of some purposive enterprise - law, education, politics, plumbing - to the point where they see with its eyes and walk in its ways without having to think about it. Interpretive community members are not independent agents who self-consciously choose to think and act in a certain way; if they are deeply embedded in the community they have no choice; the world just appears by the emphases and urgencies that are the community's content'. ${ }^{52}$

Becoming part of an interpretive community thus requires not so much institutional embeddedness, but being acquainted not only with the terminology, key documents, and practices, along with the hidden rules and hierarchies: Knowing the academic celebrities (and why), trustworthy publishers, leading journals, institutions, and faculties as well as the prerequisite of having read the standard treatises and articles, or being familiar with the formalities of citations, etc.

Most importantly, perhaps, one needs to know the arguments and counterarguments that have been exchanged already (and by whom). You should not try to bridge the gap between law and policy from the perspective of 'world order' without referring to McDougal, Lasswell, and Reisman. You should not 'discover' that international law has been fragmented into different 'subuniverses' without taking Guillaume, Simma, Hafner, or Koskenniemi into account. And you should certainly not talk about the colonial origins of international law as an instrument to justify oppression without being familiar with the works of Bedjaoui, Weeremantry, Anghie, or Chimni. If these criteria are met, even academics from other fields, most notably international relations, or (well-informed) journalists with non-legal backgrounds may join.

Social Media not only requires us to overthink superficial assumptions of position-based membership in interpretive communities but also the hierarchies within journals and publishers. The big publishing houses and mostcited journals can afford to be much more restrictive than blogs. By way of example, the American Journal of International Law explicitly takes pride of its impact factor and ranking and receives several hundreds of submissions each year. ${ }^{53}$ Meanwhile, and as noted above, periodicals in smaller countries

52 Stanley Fish, Winning Arguments (New York: HarperCollins 2016), 122 (eBook version).

53 See <https://ajil.scholasticahq.com/> and <https://www.cambridge.org/>; the website also embeds a video on the value of the review process, see $<$ https://youtu.be/CDuA44rx1ag/>; the rankings can be accessed at <https://scholar.google.com/>; yet, one needs to keep in mind that not all journals are included here, see Roger Alford, 'Google Rankings of the Most-Cited International Law Journals', 20 March 2013, <http://opiniojuris.org/>; for a critique of the tyranny of such numbers see Marko Milanović, 'Horrible Metrics', 24 August 2016, <www. ejiltalk.org/>. 
often focus on strengthening domestic legal traditions and, in the most extreme cases, become isolated debate clubs among scholars from the same country or region. ${ }^{54}$

Yet, blog editors have long recognised the potential to call the abovedescribed hierarchies into question by giving more weight to new voices, be they younger, ${ }^{55}$ less well-connected, or from neglected regions and institutions: AJIL Unbound 'seeks to broaden and diversify the scholarly exchanges on international law begun in the pages of [the American Journal of International Law]',56 the German Völkerrechtsblog website states the desire 'to contribute to opening up and diversifying the discourse in international legal scholarship', ${ }^{57}$ OpinioJuris 'particularly welcome[s] guest posts from women and from the Global South'58 and IntLawGrrls 'aims to give voice to women scholars, lawyers, policymakers, leaders, activists $[\ldots]$ We are particularly mindful of foregrounding voices of junior lawyers and scholars and others who are less often heard in international legal dialogue'. 59

Obviously enough, upholding minimum standards remains crucial. International law's interpretive community has always recognised the need to strike the balance between excessive gatekeeping and letting the chains of academia completely loose. There is a reason why some questions ought not to be asked - Fish explicitly mentions Holocaust denial ${ }^{60}$ - and why some people are either dispelled from or ignored by the academic community. ${ }^{61}$ Still, scholarship always stands on the verge of being a self-encapsulated field with little 'real life'-relevance.

While non-personal academic law blogs are, by their very nature, not as selective as law journals, they still have some filters in place. ${ }^{62}$ Those mentioned above (and others, most notably EJIL:Talk!) have their own advisory

54 See the footnotes and text to n. 38 .

55 OpinioJuris first started a call for 'new voices', i.e. blogposts by international law students or recent graduates in April 2013, see <http://opiniojuris.org/>.

56 See $<$ https://www.cambridge.org/ $>$.

57 See $<$ https://voelkerrechtsblog.org/>.

58 See $<$ http://opiniojuris.org/ $>$.

59 See <https://ilg2.org/>.

60 Fish (n. 52), $134 \mathrm{f}$.

61 One example would be Daniele Ganser's book on NATO's 'unlawful wars' and 'how NATO countries sabotage the UN. A chronic from Cuba to Syria', where he does not cite a single academic on the use of force, see Daniele Ganser, Illegale Kriege: Wie die NATO-Länder die UNO sabotieren. Eine Chronik von Kuba bis Syrien (Zürich: Orrell Füssli 2016); Ganser routinely laments that he has been expelled from the academic community for asking questions no one dares to ask such as NATO's role in post-World War II Europe or challenging conventional wisdom concerning $9 / 11$.

62 D’Aspremont and van den Herik (n. 8). 
boards or at least some form of academic vetting. ${ }^{63}$ No one doubts that academia's gatekeeper function to e.g. prevent unfounded claims and/or activism - for example, the confirmation bias of politically-motivated theses - from putting on pseudo-scientific clothes also extends to the online world.

$\mathrm{Be}$ as it may, some might view certain peer-review processes as being based on artificial constructions or as overly formalistic attempts to keep fundamental challenges to the status quo out of the academic arena. One may thus make use of the fact that there exist far less obstacles to setting up a blog than trying to convince a publisher to initiate yet another international law journal. As Fish put it,

'if the learned journals are keeping you and your friends out and labelling what you do "unprofessional" or "non-academic", you can start a journal of your own and devote its first issue to explaining why the current definitions of "professional" and "academic" are too narrow and mask an ideological position that is not announcing itself. In the academy it is always possible to set up a "rogue" territory where what is done is frowned upon by the conservative establishment'. ${ }^{64}$

Entire blogs or blog series - where several articles are being published jointly, often also cross-referencing to one other - can thus be set up dedicated to a certain perspective on international law - e.g. Third World Approaches to International Law (TWAIL) - or research question.

\section{Academic Tortoises}

Another reason for the disruptive potential of Web 2.0 is speed. As indicated above, the peer-review process takes time, often a lot of it. The 'first view' option or the possibility of publishing the unedited submission via SSRN and similar platforms might be helpful to react comparatively quick, but in no way enables journals to keep up with the hastiness of the internet.

The European Journal of International Law editors readily admit that

'[i]n the old days a time lag of six to nine months was considered very topical. That has become laughable - our production process, even at its best, is a tortoise to the internet hare'. ${ }^{65}$

63 The Völkerrechtsblog's 'Scientific Advisory Board' consists of some 38 'post-doctoral' members, the German Verfassungsblog 18 'associate editors' at the $\mathrm{PhD}$ or (junior) professor level, while EJIL:Talk! arguably has the most distinguished editorial team of all blogs since it includes numerous well-established (tenured) scholars.

64 Fish (n. 52), 131.

65 See <https://www.ejiltalk.org/>. 
Blog entries, in turn, can be written and published within hours after a judgement has been rendered, a resolution adopted, a military strike made, etc. Special rapporteurs or governmental advisors, in turn, may rely on such early comments in their (ad hoc-) analyses. ${ }^{66}$

This quickness itself does not cause concern. While one should not underestimate the risk of errors made in the heat of the moment, experts usually can rely on years of research and knowledge acquisition to come up with timely and still valuable analysis. By way of example, Dapo Akande and Marko Milanović wrote their comment on resolution 2249 (2015) concerning the call to fight the 'Islamic State' without actually authorising the use of force literally during night time (time difference mattered here). ${ }^{67}$ Having written the first analysis of this kind, they secured the academic sweet spot of being the main point of reference for scholars writing on this topic after them. ${ }^{68}$ While the first subsequent blog entries followed in the next days and weeks, ${ }^{69}$ journal articles were only published some seven months later. ${ }^{70}$

66 By way of example, Special Rapporteur on extrajudicial, summary or arbitrary executions Agnès Callamard not only immediately responded to the targeted killing of Iranian general Qassem Soleimani via Twitter herself (see <https://twitter.com/AgnesCallamard/status/ $1212910555809361920>$ ) but also quoted numerous blog comments in her report on this subject-matter published some six months later, see Use of Armed Drones for Targeted Killings: Report of the Special Rapporteur on extrajudicial, summary or arbitrary executions, 29 June 2020, A/HRC/44/38. The Research Services of the German Parliament (Wissenschaftliche Dienste des Deutschen Bundestags) also routinely rely on and quote blog entries, see for example their report on the legal implications of the US-British-French military strike against chemical weapons depots in Syria from 14 April 2018 (Völkerrechtliche Implikationen des amerikanisch-britisch-französischen Militärschlags vom 14. April 2018 gegen Chemiewaffeneinrichtungen in Syrien) or its assessment of the Global Compact for Safe, Orderly and Regular Migration from 30 November 2018.

67 Dapo Akande and Marko Milanović, 'The Constructive Ambiguity of the Security Council's ISIS Resolution', 21 November 2015, <www.ejiltalk.org/>.

68 One could say we could have had a problem with the anchoring, i.e. the 'cognitive bias where an individual depends too heavily on an initial piece of information offered to make subsequent judgments' <https://en.wikipedia.org/>; needless to say, their mostly descriptive findings proved to be entirely correct and the bias potential negative impact was thus limited if not non-existent.

69 See e. g. Marc Weller, 'Permanent Imminence of Armed Attacks: Resolution 2249 (2015) and the Right to Self Defence Against Designated Terrorist Groups', 25 November 2015, $<$ www.ejiltalk.org/> or Paulina Starski, "Legitimized Self-Defense” - Quo Vadis Security Council?’, 10 December 2015, <www.ejiltalk.org/>; Ralph Janik, 'Der Kampf gegen den "Islamischen Staat” - die großen Probleme liegen nicht im Völkerrecht', Junge Wissenschaft im Öffentlichen Recht, 9 December 2015, <https://www.juwiss.de/>.

70 Peter Hilpold, 'The Fight Against Terrorism and SC Resolution 2249 (2015): Towards a more Hobbesian or a more Kantian International Society?', IJIL 55 (2016), 535-555; Karine Bannelier-Christakis, 'Military Interventions against ISIL in Iraq, Syria and Libya, and the Legal Basis of Consent', LJIL 29 (2016), 1-33. 
In this sense, blogs eventually sent agorae on current legal events (such as the ones by the American Journal of International $\mathrm{Law}^{71}$ ) to the deathbed or at least made them less relevant. By the time of their publication, everything might have been said already, albeit not by everyone. This would not necessarily be a great loss but rather enable journals to focus on their key purpose, namely embedding fresh developments in a broader context and add value beyond initial reactions. Or, to put it more simply: The publication of articles that age well. ${ }^{72}$

\section{Global Reach and Access Inequality}

The final disruptive element to be mentioned here concerns dissemination and accessibility. Writing in 2000 and thus before the arrival of Social media, Bederman lamented that the exploding number of journals can only be explained by increased demand:

'But by whom? I suspect by only two constituencies: law students and international law faculty. Who else reads this stuff?'73

In contrast, blogs can be read by everyone and aim for the broadest audience possible, from those without any academic access at all or stu-

71 See e. g. the 1990 'U.S. Forces in Panama' agora in volume 84 of The American Journal of International Law from April 1990 and thus some four months after the US invasion against Manuel Noriega had begun or the 1984 Agora on 'the U.S. Action in Grenada' in volume 78 from January 1984 and thus two months after the beginning of the invasion, or, last but not least, the 'Appraisals of Nicaragua v. United States' agora in volume 81 from January 1987 and thus some six months after the decision was made.

72 To some extent, this was both foreseeable and happened already. As the European Journal of International Law's EJIL.Talk!-blog states, it might enable the editors 'to effect a certain mutation in the identity of EJIL itself: We will give increasing preference to articles which deal with the fundamentals, with First Things, which look at an "Incident" or "decision of a Tribunal" with a view to exploring wide systemic meaning; in short, to articles which we predict will have lasting value - that will be interesting four or five or more years after publication. EJIL:Talk! and EJIL may thus complement each other.' $<$ https://www.ejiltalk.org/>; Complementarity of the traditional, established journal and online contributions is also explicitly in the description of AJIL Unbound (n. 56); see also Stahn and de Brabandere (n. 7), 8: 'This trend is already visible in the relationship with blogs, where a new division of labour is taking shape. Journals appear to be moving away from coverage of specific types of discourse (e.g. current events, case commentary), in light of the comparative advantages of blogs. There is thus a trend towards self-restriction. It raises new questions what should be published in traditional form, and to what extent it is useful for journals to outsource debates to their own or other blogs (e.g. discussion of articles, review of books).'

73 Bederman (n. 36), 80. 
dents from universities facing difficulties to afford costly subscriptions. ${ }^{74}$ Starting with the headline, blog entries are also often designed for a broader audience beyond the interpretive community. ${ }^{75}$ They themselves are also shorter and usually written in more comprehensible, i.e. less academic, possibly even joking and personal manner and may thus help bridging the gap between scholarship and expert commentary in traditional media. ${ }^{76}$ Going back to Fish, academia is, across all fields, marked not only by its shared interpretive techniques, but also a shared vocabulary and knowledge of rules such as citation standards or of the history and present state of debates. When it comes to blog entries, these features are reduced to a minimum, as there is often no space and need for introductions that primarily serve to show educated readers one's familiarity with the standard texts.

Yet, given that more and more academic content is available online (at least the Digital Object Identifier [DOI] numbers of articles and specific passages of lengthy treatises via Google books) and can thus be referred to via hyperlinks (blogs entries may obviously refer to other blog entries), the line between shorter comments in journals and sophisticated blog entries is becoming increasingly fuzzy. This trend directly leads to the question of how one should characterise and handle blogs or even Tweets by academics: As 'nothing more than journalism within the epistemic community concerned'77 that should thus not be quoted or otherwise referred to in proper academic work? As somewhere in the grey area between journalism and scholarship, ${ }^{78}$ as a sui generis type of text, ${ }^{79}$ or as almost equal to journal articles or book chapters?

74 The problem of inequality when it comes to access to resources become more and more apparent in recent years of the Jessup International Law Moot Court, prompting Oxford University Press to make more and more of its content available, see e.g. <https://www.face book.com/jessupilsa/posts/our-friends-at-oxford-university-press-have-asked-us-to-sharetwo-new-content-co/2531738500199611/>.

75 Needless to say, 'clickbait' titles can also be found in traditional journals, e. g. Anthony D’Amato, 'It's a Bird, it's a Plane, it's Jus Cogens!', Conn. J. Int'l L. 6 (1990), 1-6.

76 D'Aspremont (n. 12).

77 D'Aspremont (n. 12); the author is fully aware of the irony of quoting a blog entry saying that blog entries should not be quoted in scholarly work.

78 Birkenkötter (n. 9), $132 \mathrm{f}$.

79 Birkenkötter (n. 9), referring to Alexandra Kemmerer, '(Rechts-)Wissenschaft sui generis?', 11 November 2012, <https://verfassungsblog.de/>. 


\section{Two Practical Examples of the Interaction Between Social Media and International Law}

As a final observation to highlight both the pros and cons of the impact of Social Media on international law's interpretive community, this part will conclude with a discussion of two examples of blogs and scholarly interaction, one positive, one negative: the collective effort by scholars connected via Social Media to assess states reactions to the April 2018 strikes in Syria and the hostile debates on recent International Criminal Court (ICC) decisions.

\section{a) The Good: A Blog Survey on the US-Led Strikes against Assad and the Curious Case of Article 2(4)}

There exists arguably no other field of international law more prone to academic ivory-towerism as described in the preceding section than the use of force. As scholars produce countless articles on the legality of humanitarian interventions or pre-emptive self-defence no one in states' legal departments, foreign, or defence ministries reads, they indeed risk absorbing themselves in a constructed reality where law actually plays a significant role when powerful states decide whether and how to strike militarily.

Most prominently in recent years, international law largely remained on the sidelines during the war in Syria, ${ }^{80}$ not only (as one may expect) among Assad's allies - Russia and Iran -, but also Western states. By way of example, the first US debate on launching strikes against the government of Bashar alAssad in Syria after he first used chemical weapons where only one Senator asked about the international legal basis for US strikes. ${ }^{81}$ In April 2018, then, the US (along with France and the United Kingdom) proceeded to intervene not only against the so-called 'Islamic State' (ISIS) but also against Syria itself, or, more precisely, the government of Bashar al-Assad. Although legal basis of the former had already been questionable - the US relied on a mixture of generalised national security interests, humanitarian imperatives, and, above all, Iraq's right to (collective) self-defence - the debate remained somewhat muted since no state wanted to be seen as somehow siding with

80 See Michael P. Scharf, Milena Sterio and Paul R. Williams, The Syrian Conflict's Impact on International Law (Cambridge: Cambridge University Press 2020).

81 See Julian Ku, 'Syria Insta-Symposium: Does the U. N. Charter Matter to the U. S. Senate's Deliberations on the Use of Force? Nope', 3 September 2013, <http://opiniojuris.org/> (on a side note, this title is a good example for nonchalant blog language). 
ISIS by openly and repeatedly challenging the legality of strikes against it. ${ }^{82}$ The situation was slightly different after Assad's forces purportedly used chemical weapons against their own population. This time, the target was not a non-state terrorist entity condemned by virtually the entire international community but, strictly speaking, the state of Syria. If there was wide acceptance or endorsement, the content of the prohibition of the use of force could have been changed drastically as allowing states to use force for humanitarian reasons and/or as a reaction to the use of chemical weapons (only).

Taking the possibility of such a far-reaching development seriously, a number of scholars from different regions - namely Alonso Gurmendi Dunkelberg, Rebecca Ingber, Priya Pillai, and Elvina Pothelet - openly called on active participation via Twitter to take a closer look at states' reactions to these strikes. A first blog post published at OpinioJuris on 22 April 2018 and thus eight days after the intervention 'canvassed' some 100 states of which 56 had indeed made official comments (going beyond mere state practice they also took two international organisations into account ${ }^{83}$ ). Then, with some help by active members of the blogosphere/scholars actively using Twitter, they collected, assessed, and categorised these statements by region and type of reaction (whether they supported - politically and/or legally - rejected, or refrained from clearly assessing the strikes). Some two weeks later, they updated their survey with some additional 23 states, amounting to some 133 countries and 79 reactions. ${ }^{84}$ The result was a staggering example of the possibilities of legal scholarship in the age of Social Media: Ten different types of reactions, from explicitly political and legal support of the strikes to outright condemnations including rejections as illegal. In sum, it turned out that only one state - the United Kingdom had explicitly defended their legality, namely as a humanitarian intervention in conformity with the wording of article 2(4) of the United Nations (UN) Charter. ${ }^{85}$ On the opposite end, they found that some twelve states had explicitly deemed them as illegal. The vast majority of states, however,

82 In addition to Syria, Russia and Iran did nevertheless challenge the legality of strikes against ISIS, albeit in a somewhat restrained manner, see e. g. Michael P. Scharf, 'How the War against ISIS Changed International Law’, Case W. Res. L. Rev. 48 (2016), 1-54.

83 Alonso Gurmendi Dunkelberg, Rebecca Ingber, Priya Pillai and Elvina Pothelet, 'Mapping States' Reactions to the Syria Strikes of April 2018', 22 April 2018, <https://www.justsecu rity.org/>.

84 Alonso Gurmendi Dunkelberg, Rebecca Ingber, Priya Pillai and Elvina Pothelet, 'Update: Mapping States' Reactions to the Syria Strikes of April 2018', 7 May 2018, <https:// www.justsecurity.org/>.

85 See the UK government's policy paper, Syria Action - UK Government Legal Position, 14 April 2018, <https://www.gov.uk>. 
refrained from referring to international law and rather made merely political statements.

On the basis of this research, it seems save to say that there was no change of the legal status quo. A substantial transformation of article 2(4) UN Charter as allowing for military action in situations like these had not occurred. Rather, many states followed a path already trodden in Kosovo: Illegal, maybe, but not necessarily illegitimate. The debates surrounding the inadequacies of the prohibition of the use of force between an outright ban even in cases of mass atrocities and the risk of abusive invocations of human rights protection will thus continue for the unforeseeable future. Yet, as this blog post has also shown, it will be more difficult than ever to claim that a certain rule has changed or evolved into customary international law. The gold standard has been set within days, made possible not only by the laudable endeavours of the blog authors themselves, but also, obviously to a much smaller degree, their open call for suggestions of additional state practice in the initial blog post and via Twitter. There is absolutely no reason why blog entries like this one should not be quoted in academic work. In addition, they also put additional pressure on governments or individual ministers: Their statements will not be overlooked, even if they are made in national television and in their own language.

\section{b) The Bad (and the Ugly?): The International Criminal Court vs. the 'Blogosphere'}

Nevertheless, blog entries also have dark sides. Some practitioners do not necessarily like being watched and being confronted with public reactions by those they accuse of not being familiar with their daily work. A particularly drastic example is the rift within the international criminal law interpretive community and the intense criticism by scholarly 'outsiders' via blogs or Twitter ${ }^{86}$ concerning the International Criminal Court's acquittals of JeanPierre Bemba and Laurent Gbagbo, the initial decision to refrain from opening an investigation of the Afghanistan situation (which was later overturned) and, lastly, the Appeal's Chamber judgement in the Jordan Referral re alBashir Appeal.

In the latter, scholars finally received a clear answer as to whether their complaints are being heard or taken seriously. Seemingly enraged

\footnotetext{
86 See, in general, Dov Jacobs, 'On the Impact of Online Commentary in International Criminal Law: A Vain Pursuit of a Socratic Ideal?’, LJIL 32 (2019), 615-623.
} 
by an EJIL:Talk! blog entry by Dapo Akande and comments by other scholars, ${ }^{87}$ the ICC's spokesperson - using his real name - appeared in the comment section to openly accusing Akande of not having read the judgement and refer to the (anonymous) Question and Answer (Q\&A) document - apparently written by the spokesperson - where one answer was dedicated to the 'animated discussion in blogosphere'. ${ }^{88}$ It is almost cliché-like criticism of the pitfalls of modern communication is worth quoting at length:

'In the era of social media, it is hoped that observers would properly study the Court's judgments and decisions before rushing to comment on them. Hastily made comments, particularly when made before the commentator has even read the judgment in question, will fail to appreciate the totality and nuances of the Court's reasoning, and may wholly misrepresent the decision or judgment. At the same time, those first comments appearing on social media frequently tend to dominate the ensuing discussion as they are tweeted and retweeted, regardless of their accuracy. Lawyers engaging in public commentary should exercise particular caution and remain mindful of the cardinal principles that guide the conduct of lawyers, including that of honesty, integrity and fairness. This principle adequately covers the need to be fair when criticising courts and judges. Notably, the rules of professional ethics in most legal systems impose special caution on criticism of judges and courts, not because it is wrong to criticise them, but because they are generally not in a position to respond to specific criticisms. It does not mean that judges and courts may not be criticised. It only means that they be criticised fairly. There is an ethical obligation to reflect facts and circumstances accurately and fairly. It is not enough to engage in convenient repeat of the commentaries of others, who may not have been fair to begin with. ${ }^{89}$

In the subsequent section, the Q\&A also emphasises that the accounts of critical experts were also 'properly examined and taken into account'. The document then goes on to address certain points of critique obviously raised by scholars concerning the court's judgement. As these are highly technical issues, one can clearly see the extent to which the author gave his utmost to have the final say on these matters.

87 Dapo Akande, 'ICC Appeals Chamber Holds that Heads of State Have No Immunity Under Customary International Law Before International Tribunals', 6 May 2019, and the comments by Göran Sluiter, Leila Sadat, Roger O’Keefe or Dov Jaobs, <www.ejiltalk.org/>.

88 The Q\&A is available via the blog of Dov Jacobs, $<$ https://thedovjacobs.files.wordpress. com/ $>$.

89 Q\&A (n. 88). 
A spokesperson speaking both as an academic and on behalf of an institution is a particularly worrisome example of how online debates may get out of hand if basic principles of interpretive communities are being disregarded. ${ }^{90}$ As Dov Jacobs noted,

'beyond the discussion on the relationship between traditional scholarship and new modes of communication, what should continue to unite the epistemic communities involved in the study of international criminal law is an attachment to shared values of dialogue, intellectual honesty, methodological rigor and, above all, freedom of expression. These values are crucial to guarantee our independence and academic freedom and any threat to any of these values should be combatted vigorously by everyone, both online and in traditional scholarship, as a threat to the epistemic community as a whole'. ${ }^{91}$

For what it is worth, one cannot rule out with certainty that this will not be the last time of failed interaction between practitioners or entire international organisations - i. e. the ICC via a not so anonymous Q\&A directly confronting its critiques - and scholars. More Social Media awareness will

90 Q\&A (n. 88); most importantly, in addition to Akande himself, Marko Milanović and subsequently James Sweeney then addressed the purported writer of the Q\&A as follows: 'I must say that I find it rather odd - even unprecedented - for the official spokesperson of the Court to engage in what is a proper academic debate with scholars like Dapo who have (rightly or wrongly) criticized the Court for the reasoning of its Bashir judgment. I frankly can't remember ANY spokesperson of any international tribunal acting in that way. I'm not saying necessarily that this is inappropriate, but it is definitely unusual. So, bearing that in mind, could you please answer the following questions:

1) Was your comment on this blog post made in your official capacity as the spokesperson of the Court? Or is it your private view, in your own personal capacity, and if so shouldn't you have said so?

2) Did you write that comment and the Q\&A you referred to on your own initiative, or were you instructed to do so by someone else, e. g. the President of the Court?

[Sweeney's comment:]

Marko's point is spot on. Given that elements of the 'Q\&A' are identical to the comment made here, we can infer that the Q\&A is a lengthier reaction to Dapo's OP.

With that in mind, I find the following elements of the Q\&A quite extraordinary:

"Hastily made comments [...] may wholly misrepresent the decision or judgment."

"Lawyers engaging in public commentary should exercise particular caution and remain mindful of the cardinal principles that guide the conduct of lawyers, including that of honesty, integrity and fairness."

"There is an ethical obligation to reflect facts and circumstances accurately and fairly."

Whether one agrees or not with Dapo's critique of the reasoning of the Appeals Chamber (and I do; and have for a long time on this point generally) the suggestion that commentators making rapid assessments of available materials (and clearly labelling that assessment as provisional) somehow are acting unethically is absurd.

Therefore, for me, it is not just the novelty of the spokesperson commenting here and publishing the Q\&A, but also the content of their comments that is profoundly troubling.'

91 Jacobs (n. 86), 623. 
obviously be necessary in the future. At the end of September 2020, the Independent Expert Review Group of the International Criminal Court published its 348 pages final report to multiple International Criminal Court stakeholders where it also briefly touched on the impact of blogs when discussing professional ethics and increased quasi-transparency by new means of communications, thereby putting additional pressure on judges to resign or be disqualified. ${ }^{92}$ The net result was that

'[s]uch events, whether truly inappropriate behaviour was involved or not, can impact the Court both externally and internally. The Court's reputation, credibility and trust is eroded, risking lower support by States Parties and civil society. Internally, it can affect staff productivity and welfare, and in some instances can represent a financial risk for the institution. In absence of efficient and effective instruments on ethics and prevention of conflicts of interest, the Court is less able to defend itself against its critics..$^{93}$

The consequences of these findings leave the observer with mixed feelings. Positive in the sense that increased accountability may ultimately prove an opportunity for the ICC to learn some lessons. Negative in the sense that, as nothing necessarily stays secret and that rumours about judges and other members of the court can spread like wildfires, it may deal yet another blow to its already tarnished reputation. In the age open defiance of the court by the US and challenges by African states, this would be the last thing the ICC needs.

\section{Conclusion}

Twitter and the 'Blogosphere' are here to stay. Some Journals, academic associations or even individuals maintain their own blogs, and Twitter has established itself as the go-to platform to stay up to date, share one's work, or even engage in (heated) debates, at times less about law than about politics.

Assuming the accusations of adopting extreme-relativist positions are correct, a 'Fisherian' point of view neither criticises nor endorses these develop-

92 Independent Expert Review of the International Criminal Court and the Rome Statute System, Final Report, 30 September 2020, para. 254, <https://asp.icc-cpi.int>:

'Throughout the Experts' consultations, ethics has been identified as an important topic for all stakeholders. Recent allegations of conflicts of interest, potential ethics violations or inappropriate behaviour from multiple Organs have been publicly covered and speculated upon through various articles and blog posts, and at times surfaced during trials through requests for disqualification of Judges.'

93 Independent Expert Review (n. 92), para. 255. 
ments in the digital sphere but rather simply condones them. Interpretive communities are naturally open to change, both when it comes to membership and their respective interpretive strategies.

For better or for worse, Social Media thus has the potential to transform and diversity international law academia. It has already supplemented traditional means of publishing and thereby opened membership in the interpretive community of international law and changed debates among scholars (and practitioners) to a significant degree. States, international organisations, or courts and tribunals face more open and immediate criticism by scholars than ever. Activist and academic stances become intermixed, interpretive communities within interpretive communities develop constantly.

Many of the fears from Social Media's early days have survived until this very day: It may indeed lead (or has already led?) to an inflation of (quasi-) academic production and opinions that could further contribute to the image of international law as an arbitrary and politicised science. Unequal distribution of scholarly influence can also be reflected in the size and reach of Social Media accounts. Academic discussions might end up divided into national, ideological, or regional filter bubbles. In the worst case, they are dominated by biases or ad hominem comments.

Be as it may, these negative trends are overshadowed by the benefits of Twitter and Blogs - even more so since they are also present in traditional academic exchanges. In the online realm, however, cooperation has never been easier, scholarship and the global international law debate club are more accessible than ever. The traditional guardrails become increasingly loose. Connecting and interacting with or reading from people you have never met and perhaps never will meet offline is one simple registration away. Those from the global south and with otherwise 'non-Western' perspectives in particular have countless possibilities to make themselves heard, at least if they are sufficiently active and well versed to be accepted by other members of international law's interpretive communities. In the Web 2.0, no part of the legal world needs to remain an undiscovered, mystical place. 